\section{International Scientific Journal Theoretical \& Applied Science}

\author{
p-ISSN: 2308-4944 (print) e-ISSN: 2409-0085 (online) \\ Year: $2016 \quad$ Issue: 1 Volume: 33 \\ Published: $30.01 .2016 \quad$ http://T-Science.org
}

\section{Nigora Ganievna Karimova \\ Senior researcher of the Department of \\ "Cinema \& TV"}

of the scientific research Institute of Art Studies

of the Academy of Sciences of Uzbekistan

nigorra@mail.ru

SECTION 16. Music. Cinema art. Theatre.

\title{
THE FIRST FILM SCREENINGS IN SAMARKAND
}

Abstract: In this article we are talking about the first screenings in Samarkand, as well as the conditions of the organization and implementation of screenings in private or rented premises, on the rules of content of single and stationary cinemas.

Key words: Film screenings, film shows, single and stationary cinemas, the rules of cinema, the electric theatre, the cinematograph.

Language: Russian

Citation: Karimova NG (2016) THE FIRST FILM SCREENINGS IN SAMARKAND. ISJ Theoretical \& Applied Science, 01 (33): 146-148.

Soi: http://s-o-i.org/1.1/TAS-01-33-25 Doi: crossef http://dx.doi.org/10.15863/TAS.2016.01.33.25

\section{ПЕРВЫЕ КИНОПОКАЗЫ В САМАРКАНДЕ}

Аннотация: В настоящей статье речь идет о первых кинопоказах в Самарканде, об условиях организации и осуществления киносеансов в частных или арендованных помещениях, о правилах содержания разовых и стациионарных кинематографов.

Ключевые слова: кинопоказы, киносеансы, разовые и стационарные кинотеатры, правила содержания кинематографов, электротеатр, синематограф.

В Самарканде, с 1868 года столицы Самаркандской области Туркестанского генералгубернаторства, кинематографы появились в начале XX века. Располагались они в европейской части города, застроенной одноэтажными домами из сырцового обожженного кирпича.

Градостроительная планировка предполагала тогда три главных радиальных направления - Абрамовский бульвар, Ташкентский и Каттакурганский проспекты. Радиусы как бы скреплялись поперечными улицами-дугами, главная из которых Кауфманская, где разместились престижные магазины, конторы различных фирм, рестораны, отели и жилые помещения, стала местом наибольшего средоточия построек, приспособленных для разовых кинопоказов или стационарных кинотеатров.

В одном из документов говорится об электротеатре «Модерн», размещенном в доме самаркандца Калантарова, об условиях его содержания, порядке регистрации и перерегистрации, смены его владельцев в течение одного года.
На основании свидетельства, выданного от 15 февраля 1912 года Самаркандским уездным начальником жительнице города Сарре Шимоновне Шнейдерман, она имеет право на проведение в доме Калантарова по Кауфманскому проспекту в течение года сеансов кинематографа, при условии выполнения требований п.1 «Обязательного постановления» военного губернатора Самаркандской области (от 23 декабря 1911 г. за № 25068) «О правилах содержания кинотеатров». В противном случае разрешение аннулировалось.

Перерегистрация имела место и в случае появления нового владельца кинотеатра. Так, из текста заявления жительницы Самарканда Пелагеи Георгиевны Мареш [1] и акта, подписанного специально созданной комиссией [2], с 26 марта 1913 года «ответственным лицом на время действия кинематографа» является уже не С.Ш. Шнейдерман, а П. Г. Мареш. Через несколько месяцев, т.е. в июле того же года, решением Самаркандского уездного начальника ответственность за кинематограф переходила к другому лицу - Жанне Станиславовне Янжуль [там же].

ISPC Perspectives in science for 2016, 
Для получения всего имущества кинотеатра уездное начальство направляло письмо на имя полицмейстера города, который и осуществлял непосредственную передачу «принадлежностей кинематографа» [2]. Однако 10 сентября на имя уездного начальства города поступает заявление от жителя Самарканда Мулло Умара Абдугафарова, который просит, с согласия и письменной доверенности со стороны Ж. С. Янжуль, перерегистрировать свидетельство на его имя для проведения киносеансов в этом кинотеатре. Он пишет: «Ж. С. Янжуль передала мне свой кинематограф, указанный в прилагаемом при сем свидетельстве с надписью о передаче» [3].

Прошение Муллы Умара Абдугафарова, названного в ответном письме туземцем, было положительно рассмотрено и выдано свидетельство за № 3802, на основании которого ему разрешается открыть сеансы кинематографа в 1913 г. в доме Калантарова по Кауфманской улице [4]. Как следует из документов, дом под киносеансы сдавался в аренду.

Бывали случаи организации и эксплуатации кинотеатров в собственных домах. В архивах сохранилось письмо Андрияса Карапетовича Саямова от 24 марта 1913 года на имя уездного начальника города с просьбой создать комиссию по осмотру готовности кинотеатра «Гранд-био» к продолжению кинопоказов в 1913 году, так как лицензия заканчивалась [5]. Сохранилась копия подписанного членами комиссии акта, в котором указывалось, что никаких нарушений нет, «а потому на действия кинематографа в этом здании в 1913 году препятствий не имеется» [6].

11 мая 1913 года А. К. Саямов, в целях расширения финансовой отдачи кинотеатра, обратился с просьбой о разрешении открыть во дворе того же дома летний кинотеатр [6]. Следующий документ - это акт, составленный членами комиссии по проверке условий для открытия летнего кинотеатра во дворе А. К. Саямова. Он свидетельствует о строгом отношении властей к условиям показа и соблюдении правил Обязательного постановления и для летних кинотеатров. В этом акте было указано 9 пунктов нарушений, по исправлении которых «препятствий к открытию временного кинематографа не встречается» [7].

В октябре того же года А. К. Саямов сдает свой кинематограф в аренду, о чем свидетельствует письмо от жительницы Самарканда Елизаветы Сергеевны Скриплевой: «...приняв в аренду от Андрияса Карапетовича Саямова синематограф «Гранд-Био», настоящим честь имею просить ... о переводе выданного г. Саямову свидетельства за № 1583, которое при сем прилагаю, на мое имя по доверенности» [8].
На Кауфманской улице можно было найти еще ряд кинотеатров, из которых отдельные были связаны с домом Калантарова. Так, после осмотра помещений кинематографов «Феномен» и «Олимпия» жителю Самарканда Ари Абрамовичу Фузаилову в апреле 1913 г. дано разрешение на летний показ фильмов [9]. Разрешение для летнего показа в кинотеатре «Олимпия» было дано Александру Николаевичу Давыдову, откуда следует вывод, что один и тот же кинотеатр одновременно использовался несколькими заявителями [10].

Кинотеатры открывались и в старой части города, о чем свидетельствует заявление на имя начальника Самаркандского уезда, поступившее 30 апреля 1913 г. от неграмотной жительницы Самарканда А. Н. Роговской («по безграмотности и ея личной просьбе расписался - С. М. Палтуев»). В нем содержится просьба о «назначении комиссии для освидетельствования вновь открытого ... кинематографа в туземной части города Самарканда, в сарае Мукумбая Фазыльбаева, где и в прошлом году функционировал синематограф» [11].

Через неделю, а именно 7 мая 1913 г., принято постановление о создании комиссии по проверке этого заявления. 10 мая комиссия произвела осмотр помещения «на предмет разрешения в этом дворе кинематографических картин» и выявила целый ряд нарушений, характеризующих состояние кинопоказа своего времени: а) отсутствие фонарей на наружных выходах; б) выходы расположены под навесами двухэтажного каркасного дома; в) ряды скамеек не прикреплены к земле и не имеют проходов положенного размера; г) не имеется ручных огнетушителей; д) не имеется телефона; е) не имеется надписи о количестве мест; ж) аппаратная камера расположена частью под балаханой [12].

19 мая 1913 г. та же заявительница А. Н. Роговская вновь обращается с письмом, в котором указывает, что все нарушения, перечисленные в акте комиссии, ею исправлены [13].

О взыскательности и требовательности комиссий по осмотру и проверке условий показа картин свидетельствует следующий документ это заявление А. П. Бомбчинского - «содержателя синематографа «Юлдуз» в туземной части города Самарканда по Регистанской улице, в сарае Жура-бая» от 5 июня 1913 г. Он переделал временный зрительный зал в стационарный и в связи с этим обратился к начальству города с просьбой дать разрешение на дальнейший просмотр.

А второй документ - это уже собственно акт, подписанный членами комиссии, назначенной в целях проверки условий 
содержания кинотеатра вышеуказанным А. П. Бомбчинским. Здесь указан целый ряд отступлений от правил. Причем, наряду с привычными нарушениями технического характера, есть необычное замечание, позволяющее представить историческую атмосферу и конкретную среду, в которой проходили первые киносеансы: «В караван-сарай, во дворе которого помещается кинематограф, во время демонстрирования картины необходимо в противопожарном отношении не допускать под навесами стоянки лошадей, ослов и прочего скота» [14].

К 1913 г. в Самарканде действовали уже не просто индивидуальные владельцы, но и сообщества. Так, в архиве сохранилось и прошение от 23 марта 1913 г. «на право демонстрирования $\quad$ в $1913 \quad$ г. синематографических картин» от товарищества электротеатра «Прогресс», расположенного на Пенджикентской улице, в доме некоего И. Ильясова [15].

Кинематограф того времени в Самарканде во многом воспринимался как развлекательный, аттракционный вид досуга. Вероятно, особой популярностью у местного населения пользовался просмотр фильмов во время традиционных весенних празднеств на Афрасиабе - древнем городище Самарканд, где проводились гулянья и различные представления. Об этом свидетельствуют документы, в которых синематограф упомянут в одном ряду с другими видами массовых балаганных развлечений.

Так, в своем письме от 17 марта 1913 г. на имя городского депутата Г. Михайлова, Самаркандский уездный начальник пишет: «В дополнение к предписанию моему от 12 марта сего года за №1301 предлагаю Вам теперь же взыскать в пользу города по 10 рублей со всех построенных на Афрасиабе на время туземного праздника цирков, синематографов, каруселей и пр.» [16].

Судя по этому документу, цирки, качели, кинопоказы на Афрасиабе были весьма распространены и устраивались в период весеннего праздника Сайиля.

В своем письме от того же числа, но уже на имя пристава 3 части города Самарканда уездный начальник пишет: «... в местности Афрасиабе построено несколько синематографов и цирков без надлежащего на то разрешения городского хозяйственного управления. Поэтому прошу распоряжения о прекращении действия вышеуказанных цирков и синематографов, впредь до получения ими соответствующего разрешения... и оказать содействие городскому депутату Михайлову по взысканию за места в той же местности, занятые цирками, синематографом» [17].

В архивах сохранился ряд документов, содержащих прошение жителей Самарканда к городским властям дать разрешение на «демонстрирование кинематографических картин» именно в период Сайиля и соответствующие, выданные на основе проверки удостоверения [18]. Письма подавались в первых числах марта, чтобы получить разрешение накануне народных гуляний в дни Навруза.

В процессе составления прошений и свидетельств взимался гербовый сбор в виде марок, приклеенных к каждому прошению на имя начальника Самаркандского уезда (1913) и стоивших 3 рубля. Так, после многократных обращений, которые указывали на многочисленные нарушения, не было выдано свидетельства для кинематографа в туземной части города Самарканда, во дворе дома Фазильбаева [19].

\section{References:}

1. TSGA RUz, f. I-20, op. 1, yed. khr. 1659, 1. 73.

2. TSGA RUz, f. I-20, op. 1, yed. khr. 1659, 1. 76.

3. TSGA RUz, f. I-20, op. 1, yed. khr. 1659, 1. 36.

4. TSGA RUz, f. I-20, op. 1, yed. khr. 1659, 1. 37.

5. TSGA RUz, f. I-20, op. 1, yed. khr. 1659, 1. 53.

6. TSGA RUz, f. I-20, op. 1, yed. khr. 1659, 1. 56.

7. TSGA RUz, f. I-20, op. 1, yed. khr. 1659, 1. 84.

8. TSGA RUz, f. I-20, op. 1, yed. khr. 1659, 1. 48.

9. TSGA RUz, f. I-20, op. 1, yed. khr. 1659, 1. 42.

10. TSGA RUz, f. I-20, op. 1, yed. khr. 1659, 1. 63.

11. TSGA RUz, f. I-20, op. 1, yed. khr. 1659, 1. 61.
12. TSGA RUz, f. I-20, op. 1, yed. khr. 1659, 1. 66.

13. TSGA RUz, f. I-20, op. 1, yed. khr. 1659, 1. 68.

14. TSGA RUz, f. I-20, op. 1, yed. khr. 1659, 1. 39.

15. TSGA RUz, f. I-20, op. 1, yed. khr. 1659, 1. 21.

16. TSGA RUz, f. I-20, op. 1, yed. khr. 1659, 1. 22.

17. TSGA RUz, f. I-20, op. 1, yed. khr. 1659, 1. 25, 26, 27, 28, 24.

18. TSGA RUz, f. I-20, op. 1, yed. khr. 1659, 1. 61.

19. TSGA RUz, f. I-20, op. 1, yed. khr. 970, 1. 2-2b. 